\title{
History, Taxonomy and Propagation of Moringa oleifera-A Review
}

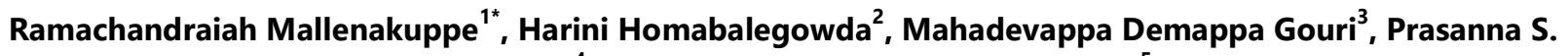 \\ ${\text { Basavaraju }{ }^{4} \text {, Umashankar B. Chandrashekharaiah }}^{5}$ \\ ${ }^{1}$ Veterinary Officer, Department of AH \& VS, Govt. of Karnataka, Ramanagar, Karnataka, India \\ ${ }^{2} \mathrm{PhD}$ Scholar, Department of Animal Genetics and Breeding, Veterinary College, Hebbal, Bengaluru, Karnataka, India \\ ${ }^{3}$ Assistant Professor, Department of Livestock Production and Management, Veterinary College, Hebbal, Bengaluru, \\ Karnataka, India \\ ${ }^{4}$ Assoicate Professor (I/C), Department of LFC, Veterinary College, Hebbal, Bengaluru, Karnataka, India \\ ${ }^{5}$ Assistant Professor, Department of Animal Nutrition, Veterinary College, Hebbal, Bengaluru, Karnataka, India
}

*Address for Correspondence: Dr. Ramachandraiah Mallenakuppe, Veterinary Officer, Department of AH \& VS, Govt. Of Karnataka, Ramanagar, Karnataka, India

E-mail: drramachandragowda@gmail.com

Received: 15 Oct 2018/ Revised: 22 Feb 2019/ Accepted: 25 Apr 2019

\begin{abstract}
India is one of the fastest developing countries in the world. Presently India has the largest livestock population in the world. With the increase in the human population, to meet the present and future demands of this population, certain new strategies are to be adapted to meet the input requirements and also to enhance the production potential of Indigenous as well as crossbred cattle and other class of livestock for production, reproduction and they are by-products. Current work about the compilation of review works presented by various research works depicts the status and factors responsible for under utilization of Moringa oleifera ( $M$. oleifera). Especially with respect to the knowledge on taxonomy, distribution, diverse utilizations, nutritional value, socioeconomic importance, morphological and genetic diversity, domestication, propagation and management of $M$. oleifera is concerned. For fulfilling the Knowledge gaps, research and development avenues, we were suggested and discussed for improved valorisation. Since $M$. oleifera contains most of the nutrients which are required for all classes of livestock including poultry and fish, and even in human moringa leaves are used as tea powder, as a leafy vegetable etc. M. oleifera is also a good source of minerals and essential amino acids. The use of moringa can be extended in the pig as well as rabbit reproduction also. Therefore, the characteristics of Moringa make it be considered as one of the world's most useful trees. Better nutritional quality and high biomass production, especially in dry period support its significance as livestock fodder.
\end{abstract}

Key-words: Livestock fodder, Moringa oleifera, Nutritional value, Propagation, Taxonomy

\section{INTRODUCTION}

Each part of the Moringa tree (fruits, seeds, leaves, flowers, bark and roots) is associated with the presence of at least one, or in most number of benefits. $M$. oleifera is one of the world's mostly used plants. All parts of the species are traditionally used for different purposes, but leaves are generally the most used all over

How to cite this article

Mallenakuppe R, Homabalegowda H, Gouri MD, Basavaraju PS, Chandrashekharaiah UB. History, Taxonomy and Propagation of Moringa oleifera-A Review. SSR Inst. Int. J. Life Sci., 2019; 5(3): 2322-2327.

\begin{tabular}{|c|c|}
\hline & Access this article online \\
https://iijls.com/
\end{tabular}

the world. Fodder scarcity and Low quality of available fodder are considered to be the major constraints hampering the productivity of farm animals. The available feed particularly in a dry season when natural pastures are mature is highly fibrous and inadequate with low nutritive value due to low crude protein content ${ }^{[1]}$.

Moringa species are all native to Asia, from where they have been propagated across many parts of the world especially more seen in warm countries, such as Malaysia and other tropical countries. This tree can tolerate temperatures from $19^{\circ} \mathrm{C}$ to $28^{\circ} \mathrm{C}$, and has height from 5 to $10 \mathrm{~m}$ and can be cultured throughout the plains. Moringa leaves are being used as a medicine because it is said to contain many phyto-chemicals, hence it is used as preventive and curative purposes ${ }^{[2]}$. 
Many underutilized crops and trees are the main target for the studies by plant scientists, nutritionists, and growers. Of the many plant and tree verities, Moringa oleifera is one of these, which has been neglected since several years, but of late the moringa is being investigated for its fast growth, higher nutritional attributes, and utilization as a livestock fodder crop. Moringa can be grown in areas where growing of other crops is difficult. It can also be grown as a crop on marginal lands with high temperatures and low water availability $^{[3-6]}$.

M. oleifera are originated in sub-Himalayan tracts of the Indian sub-continent. This is one of the fast growing, evergreen, deciduous medium sized perennial tree of about $10 \mathrm{~m}$ to $12 \mathrm{~m}$ height. The bark has whitish-grey colour and is surrounded by thick cork. Young shoots have purplish or greenish-white bark. Flowers are yellowish creamy white and sweet smelling. The matured fruit is a hanging capsule of $20-45 \mathrm{~cm}$ size having 15 to 20 dark brown globular seeds of 1 to $1.2 \mathrm{~cm}$ diameter ${ }^{[7]}$. At present country facing the deficit of green, dry and concentrate at the level of $63.5 \%, 23.5 \%$, and $64 \%$ respectively as a result the $\mathrm{CP}$ and TDN availability are not meeting the requirement causing deficit of about $26.5 \%$ and $23.70 \%$ respectively ${ }^{[8]}$. Further due to everincreasing population pressure of human beings, arable land is mainly used for food and cash crops, thus there is little chance of having good quality arable land available for fodder production unless milk production becomes remunerative to the farmer as compared to other crops. The unconventional fodder resources such as Azola, moringa, sesbania, cactuses, etc are emergency fodders with high nutritive values ${ }^{[9]}$.

Table 1: Area under fodder crop ${ }^{[8]}$

\begin{tabular}{cccc}
\hline Area (mh) & 1990 & 2010 & 2020 \\
\hline $\begin{array}{c}\text { Gross cropped } \\
\text { area (excluding } \\
\text { fodder crop) }\end{array}$ & 174.1 & 188.1 & 196.8 \\
$\begin{array}{c}\text { Area under fodder } \\
\text { crop }\end{array}$ & 8.26 & 7.88 & 7.09 \\
$\begin{array}{c}\text { Permanent } \\
\text { pastures and } \\
\text { grazing land } \\
\text { Land under }\end{array}$ & 11.3 & 10.2 & 9.49 \\
$\begin{array}{c}\text { miscellaneous tree } \\
\text { crops }\end{array}$ & 3.8 & 3.28 & 3.15 \\
\hline
\end{tabular}

To meet the current level of livestock production and its annual growth in population, the deficit in all components of fodder, dry crop residues, and feed has to be met through increasing productivity, utilizing untapped feed resources, increasing cultivable land area or through imports.

Trees and browse species like Subabul, Morus, Glyricidia and Sesbania have been used as livestock fodder for centuries in India and many other countries. Most trees and shrubs are easily propagated and not require high management inputs (fertilizers and pesticides) or advanced technology.

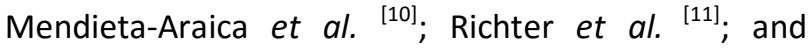
Sanchez et al. ${ }^{[12]}$ have explored $M$. oleifera cultivation and propagation practices and its utilization as livestock fodder and also in fish diet. The results of their studies showed that moringa species has great potential as livestock fodder.

Natural history, range and growing condition of $M$. oleifera- $M$. oleifera is a widespread multipurpose tree reported to have nutritional, therapeutic and prophylactic properties with several industrial applications. It is well known to the ancient world, but only recently it has been rediscovered due to the tremendous variety of its potential uses. It is a fast growing, a perennial tree which can reach a maximum height of 7 to $12 \mathrm{~m}$ up to the crown ${ }^{[13]}$ and found growing naturally at elevations of up to $1000 \mathrm{~m}$ above sea level. It can grow well on hillsides, but is more frequently found growing on pasture land or in river basins as a non-cultivated plant.

M. oleifera belongs to the monogeneric family of shrubs and tree Moringaceae, considered to have its origin in Agra and Oudh, in the northwest region of India and south of the Himalayan Mountains. It is now cultivated throughout the Middle East, almost the whole tropical belt and it was introduced in Eastern Africa from India at the beginning of $20^{\text {th }}$ century.

About 33 species have been reported in the family Moringaceae ${ }^{[14]}$. Among those, thirteen species namely, M. arborea, M. borziana, M. concanensis, M. drouhardi, $M$. hildebrandtii, M. longituba, M. oleifera, M. ovalifolia, M. peregrina, $M$. pygmaea, $M$. rivae, M. ruspoliana, $M$. stenopetala are well known and found worldwide. 
Table 2: Taxonomic position of $M$. oleifera

\begin{tabular}{cl}
\hline Kingdom & Plantae \\
\hline Superkingdom & Tracheobionta \\
Superdivision & Spermatophyta \\
Division & Magnoliophyta \\
Class & Magnoliopsida \\
Subclass & Dilleniidae \\
Order & Capparales \\
Family & Moringaceae \\
\hline
\end{tabular}

Table 3: Geographic distribution of documented thirteen Moringa species

\begin{tabular}{|c|c|}
\hline Species & Geographical location \\
\hline \multicolumn{2}{|c|}{ Slender trees } \\
\hline M. concanensis & India \\
\hline M. oleifera & India \\
\hline M. peregrine & $\begin{array}{c}\text { Fiori Red Sea, Arabia, Horn } \\
\text { of Africa }\end{array}$ \\
\hline \multicolumn{2}{|c|}{ Bottle trees } \\
\hline M. drouhardii & Madagascar \\
\hline M. hildebrandtii & Madagascar \\
\hline M. ovalifolia & Namibia and S.W. Angola \\
\hline M. stenopetala & Kenya and Ethiopia \\
\hline \multicolumn{2}{|c|}{ Tuberous shrubs and herbs of North Eastern Africa } \\
\hline M. arborea & North Eastern Kenya \\
\hline M. borziana & Kenya and Somalia \\
\hline M. longituba & Kenya, Ethiopia, Somalia \\
\hline M. pygmaea & North Somalia \\
\hline M. rivae & Kenya and Ethiopia \\
\hline M. ruspoliana & Kenya, Ethiopia, Somalia \\
\hline
\end{tabular}

Table 4: Some common names of $M$. oleifera ${ }^{[15]}$

\begin{tabular}{|c|c|c|c|}
\hline Language & $\begin{array}{c}\text { Common } \\
\text { Name }\end{array}$ & Language & $\begin{array}{c}\text { Common } \\
\text { Name }\end{array}$ \\
\hline Kannada & Nugge & Sanskrit & Shobhanjana \\
\hline Tamil & Murungai & Telegu & $\begin{array}{c}\text { Munaga, } \\
\text { Tellamunaga }\end{array}$ \\
\hline Urdu & Sahajna & Konkani & $\begin{array}{c}\text { Maissang, } \\
\text { Moxing }\end{array}$ \\
\hline Punjabi & Sainjna & Marathi & $\begin{array}{c}\text { Achajhada, } \\
\text { Shevgi }\end{array}$ \\
\hline Hindi & saijna, shajna & English & $\begin{array}{c}\text { Drumstick } \\
\text { tree }\end{array}$ \\
\hline Malayalam & murinna, sigru & Assamese & $\begin{array}{l}\text { Saijna, } \\
\text { Sohjna }\end{array}$ \\
\hline Gujarati & Midhosaragavo & Chinese & La ken \\
\hline
\end{tabular}

Production and management of $M$. oleifera is easy due to its fast growth, low demand for soil nutrients and water after being planted especially in later stages, high capacity to resprout after harvesting make it to perform better under marginal conditions with ample nutritional quality ${ }^{[16]}$.

Table 5: Ecological Requirements of $M$. oleifera ${ }^{[3]}$

\begin{tabular}{cc}
\hline Parameter & Requirement/range \\
\hline Climate & Tropical or sub-tropical \\
Altitude/Height & $0-2000$ meters \\
Temperature & $18.7-28.5^{\circ} \mathrm{C}$ \\
Rainfall & $250 \mathrm{~mm}-2000 \mathrm{~mm}$. \\
& Irrigation needed for leaf \\
Soil type & Loduction if rainfall <800 mm sandy or sandy-loam \\
Soil $\mathrm{pH}$ & Slightly acidic to slightly alkaline \\
& (pH 5 - 9)
\end{tabular}

Its roots penetrate deep into the soil to search for water and nutrients, which enables Moringa trees to tolerate severe conditions. Relatively low requirements of irrigation-make Moringa superior to some other livestock meals like soybean, cotton seed cake, and range grasses which require intensive irrigation makes it too difficult to cultivate for small livestock farmers ${ }^{[17]}$. M. oleifera can be grown in diverse soils, including hot, humid, dry tropical and subtropical regions except for waterlogged conditions. Slightly 
alkaline clay and sandy loam soils are considered the best media for this species due to their good drainage [18].

Table 6: Undesirable sites for Moringa cultivation ${ }^{[19]}$

\begin{tabular}{|c|c|}
\hline Site & Reason(s) \\
\hline $\begin{array}{l}\text { Industrial waste } \\
\text { dumps }\end{array}$ & $\begin{array}{l}\text { Absorption of undesirable or } \\
\text { toxic heavy metals e.g. } \\
\text { mercury, arsenic, lead, etc. }\end{array}$ \\
\hline Refuse dumps & $\begin{array}{l}\text { Absorption of undesirable or } \\
\text { toxic heavy metals e.g. } \\
\text { mercury, arsenic, lead, etc. }\end{array}$ \\
\hline Waterlogged sites & $\begin{array}{c}\text { Poor drainage causes roots to } \\
\text { rot. e.g. rice fields, clay, river } \\
\text { beds, etc. }\end{array}$ \\
\hline $\begin{array}{l}\text { Termite infested } \\
\text { soils }\end{array}$ & $\begin{array}{c}\text { Destruction of young and } \\
\text { mature trees }\end{array}$ \\
\hline $\begin{array}{l}\text { Animal grazing } \\
\text { fields }\end{array}$ & $\begin{array}{c}\text { Destruction of young and } \\
\text { mature trees }\end{array}$ \\
\hline
\end{tabular}

Daba's research reported by Japanese has displayed that the rate of absorption of carbon dioxide by the Moringa tree is twenty times higher than that of general vegetation. The capacity of the Moringa tree is inspiring in mitigating the adverse effects of climate change ${ }^{[20]}$.

The morphological parts of $M$. oleifera include stem, branch, leaves, flowers, fruits with the seeds. Fruits are tri-lobed pods contain 12-35 seeds, each tree can produce $15000-25000$ seeds/year, the average weight per seed is $0.3 \mathrm{~g}$ and the kernel to hull ratio is $75: 25^{[21]}$.

Propagation of Moringa- Moringa can be propagated by direct seed planting, seedling transplanting and mature stem cuttings. Direct seeding is preferable when the germination rate is high. Seeds must be sown at a maximum depth of $2 \mathrm{~cm}$ as deeper seeding might reduce the germination rate. There are around 4000 Moringa seeds (with their shell) in a kilo with the germination percentage of $78-94 \%$. Moringa seeds germinate 5 to 12 days after seeding ${ }^{[22]}$.

Seedlings are grown in polythene bags or sacks prefilled with topsoil by sowing seeds at $2 \mathrm{~cm}$ depth and watering once in every 2-3 days. After showing they have to be placed in a slightly shaded area and also protect from heavy rains. The young Moringa plants must be nursed for 4 weeks before transplanting for better survival rate when they are about $30 \mathrm{~cm}$ high. Remove the polythene bag when transplanting ensuring that the roots of the plant are not damaged. Hardwood cuttings of $40 \mathrm{~cm}$ long and 4 to $5 \mathrm{~cm}$ in diameter ${ }^{[23]}$, can also be used for propagation by burying one-third of the stem in the soil. Plants produced with cuttings will not have a deep root system will be more sensitive to wind drought and termite attacks.

Seed production- Spacing must be much wider for fruit or seed production. Trees must be at least $2.5 \mathrm{~m}$ apart line and peg using a $3 \times 3 \mathrm{~m}$ triangular pattern for seed producing farms.

Limitations- Apart from its advantage as high biomass yielding and highly nutritious fodder for both human and livestock there are many limitations for intended cultivation and utilization. Not suitable for cultivation in the highly irrigated area. Lack of exact package, practices to cultivated moringa for fodder production, whereas lack of preservation and processing technology under local conditions. Insufficient researches to validate the level of inclusion under local condition. It can never be used as a sole source feed and fodder for livestock because of its high level of Crude Protein, which has to be balanced with energy. Since the moringa leaves are also used as a vegetable for human beings creates demand and eventual cost hike.

\section{CONCLUSIONS}

M. oleifera is a multipurpose plant with the potential to reduce the dependence on expensive conventional protein supplements, the relative ease with which Moringa can be propagated through both sexual and asexual means, low demand of soil nutrients and water. Moringa has almost all essential nutrients in adequate amounts for maintenance and production; provide macro and micronutrient to boost the nutritive value of the feed. Due to high nutritive value, Moringa has been used as a feed supplement in most livestock species and poultry. Its supplementation not only increases meat and milk production but also the quality, healthfulness and shelf life of the product.

The future prospects of $M$. oleifera to be explored in terms of the proper sowing densities and harvesting frequencies, information on agronomical practices, planting densities and cutting frequencies for getting maximum biomass with good nutritional quality need to be explored, studies directed towards the detection and commercialization of bioactive compounds to the 
development of remedies for several ailments. Besides this, its fertilizer and irrigation requirements as a fodder crop have not yet been studied, which needs attention for more biomass production. Finally, the policymakers, researchers and extension institutions should formulate programs focusing on generating awareness among local communities and farmers, especially among those, who are engaged in livestock production, to emphasize the planting of Moringa as a "FOOD-FEED" crop for their family and their livestock.

\section{ACKNOWLEDGMENTS}

Since the article is of Review nature no financial support was required only the efforts put to compile the article was immense from all the co-authors more specifically my mentor Dr. Mahadevappa D. Gouri, I thank him for his motivation and guidance for this to happened.

\section{CONTRIBUTION OF AUTHORS}

Research concept- Mahadevappa D. Gouri

Research design- Mahadevappa D. Gouri,

Ramachandraiah

Supervision- Umashankar, Mahadevappa D. Gouri

Materials- Ramachandraiah, Mahadevappa D. Gouri

Data collection- Ramachandraiah, Mahadevappa D. Gouri

Data analysis and Interpretation- Ramachandraiah,

Mahadevappa D. Gouri, Harini

Literature search- Ramachandraiah, Harini

Writing article- Ramachandraiah, Mahadevappa D. Gouri

Critical review-Mahadevappa D Gouri, Prasanna

Article editing- Ramachandraiah, Mahadevappa D. Gouri

Final approval- Ramachandraiah, Mahadevappa D. Gouri, Umashankar, Prasanna

\section{REFERENCES}

[1] Moyo B, Masika PJ, Muchenje V. Effect of supplementing crossbred Xhosa lop-eared goats castrates with Moringa oleifera leaves on growth performance, carcass and non-carcass characteristics. Trop. Anim. Health and Prod., 2012: 44(4): 801-09.

[2] Udikala M, Verma Y, Sushma, Lal S. Phytonutrient and Pharmacological Significance of Moringa oleifera. Int. J. Life. Sci. Scienti. Res., 2017: 3(5): 1387-91.

[3] Nouman W, Siddiqui MT, Basra SMA. Moringa oleifera leaf extract: An innovative priming tool for rangeland grasses. Turk. J. Agric. For., 2012; 36: 65-75.
[4] Nouman W, Siddiqui MT, Basra SMA, Afzal I, Rehman $\mathrm{H}$. Enhancement of emergence potential and stand establishment of Moringa oleifera Lam. by seed priming. Turk. J. Agric. For., 2012; 36: 227-35.

[5] Nouman W, Siddiqui MT, Basra SMA, Farooq H, Zubair $\mathrm{M}$, et al. Biomass production and nutritional quality of Moringa oleifera as field crop. Turk. J. Agric. For., 2013; 37: 410-19.

[6] Wasif N, Shahzad B, Muhammad TS, Azra Y, Tehseen $G$, et al. Potential of Moringa oleifera $L$. as livestock fodder crop: A review. Turk. J. Agric. For., 2014; 38: 1-14. 10.3906/tar-1211-66.

[7] Singh D, Moringa Cultivation for Green Fodder by NDDB. Accessed on $22^{\text {nd }}$ April, http://www.dairyknowledge.in/sites/default/files/m oringa-oleifera-eng.pdf and also available on facebook.com/NationalDairyDevelopmentBoard, 2018.

[8] Datta D. Indian Fodder management towards 2030: A Case of Vision or Myopia. Int. J. Manag. Soc. Sci. Res., 2013; 2(2): 33-41.

[9] Gouri, Mahadevappa D, Sanganal JS, Gopinath CR, Kalibavi CM. Importance of azolla as a sustainable feed for livestock and poultry. Agric. Review, 2012; 33(2): 93-103.

[10]Mendieta-Araica B, Sporndly R, Sanchez NR, Sporndly E. Moringa (Moringa oleifera) leaf meal as a source of protein in locally produced concentrates for dairy cows fed low protein diets in tropical areas. Livestock Sci., 2011; 137: 10-17.

[11]Richter N, Perumal S, Klaus, B. Evaluation of nutritional quality of moringa (Moringa oleifera Lam.) leaves as an alternative protein source for Nile tilapia (Oreochromis niloticus L.). Aquacul., 2003; 217: 599-611.

[12]Sanchez NR, Stig L, Inger L. Biomass production and chemical composition of Moringa oleifera under different management regimes in Nicaragua. Agrofores. Sys., 2006; 66: 231-42.

[13]Makkar HPS, Becker K, Nutrients and anti quality factors in different morphological parts of Moringa oleifera tree. J Agri Sci., 1997; 128: 311-22.

[14]Arora, DS, Onsare JG, Kaur H. Bioprospecting of Moringa (Moringaceae): Microbiological perspective. J. Pharmacog. Phytochem., 2013; 1: 193-215. 
[15] Koul B, Neikuozo Chase N. Moringa oleifera Lam.: Panacea to several maladies. J. Chem. Pharm. Res., 2015; 7(6): 687-707.

[16] Odee D. Forest biotechnology research in drylands of Kenya: the development of Moringa species. Dryland Biodivers., 1998; 2: 07-08.

[17] Benavides JE. Researching trees for forestry. In: Trees and Shrubs in Central America, 1994; 1(3): 28.

[18]Ramachandran C, Peter KV, Gopalakrishnana PK. Drumstick (Moringa oleifera): A multipurpose Indian vegetable. Econ. Bot., 1980; 34: 276-83. doi: 10.1007/BF02858648

[19]Sauveur, AD, Melanie B. Growing and processing moringa leaves. Moringa news/Moringa Association of Ghana, 2010; 01-69.
[20]Daba M. Miracle Tree: A Review on multi-purposes of Moringa oleifera and its implication for climate change mitigation. J. Earth Sci. Clim. Change, 2016; 7(8): 366.

[21]Makkar HPS. Becker K. Plant toxins and detoxification methods to improve feed quality of tropical seeds. Asian-Australas. J. Anim. Sci., 1998; 12: 467-80.

[22]Choudhary LC, Kumara DN, Neeta A, Ravindra K. Evaluation of Moringa oleifera leaves in Sheep. Indian J. Anim. Nutr., 2006; 23(3): 196-98.

[23] Lawal BA, Olawepo TF, Asaolu VO, Akanbi WB, Jolaos $O$, et al. Effect of different methods of establishment on growth and biomass yield of Moringa (Moringa Oleifera Lam). Intl. J Agri. Crop Sci., 2015; 8(4): 650-53. 